\title{
Psychology's Factors of Stock Buying and Selling Behavior in Indonesia Stock Exchange (Phenomenology Study of Investor Behavior in Surabaya)
}

\author{
Sri Utami Ady ${ }^{1}$, Made Sudarma ${ }^{2}$, Ubud Salim ${ }^{3}$, Siti Aisyah ${ }^{4}$ \\ ${ }^{I}$ (Economic and Business Faculty, Brawijaya University, Indonesia) \\ ${ }^{2}$ (Economic and Business Faculty, Brawijaya University, Indonesia) \\ ${ }^{3}$ (Economic and Business Faculty, Brawijaya University, Indonesia) \\ ${ }^{4}$ (Economic and Business Faculty, Brawijaya University, Indonesia)
}

\begin{abstract}
This study aims to explore the investment understanding and to construct implementation the investment meaning to investment behavior, as well as to construct the model design of investor decisionmaking behavior in stock buying and selling for short-term investor in Surabaya. This study used a qualitative interpretive paradigm, with phenomenology deontology method. Behavioral finance theory perspective was used as a tool to analyze the results. The results showed that: (1) Compared with fundamental analysis and technical analysis, well emotions management based on age, gender, education and personality of investor/trader was central in determining the success, (2) Compared with other short term investor type, such as a swing trader, position trader and historical investors, the day traders have greatest psychological burden in decision to buy or to sell shares, (3) Short-term investors can manage emotions rightly to obtain greater benefit from short-term investments than long-term investments, (4) experience was the best teacher for trader journey. Traders who able to learn from experience would be better than the traders who understand the stock market science but lack of experience, because the decisions based on a combination of rational and intuitive.
\end{abstract}

Keywords: investor behavior, behavioral finance, qualitative, interpretive, phenomenology

\section{Introduction}

The research was motivated by stock investor's behavior phenomenon that tends to be more influenced by psychological factors, such as herding behavior. Herding was investors behavior that buying and selling shares by following the foreign investors behavior, although the condition of Indonesia's economic fundamentals was good. Therefore, the Composite Stock Price Index declined sharply. Next investor behavior was "noise trading behavior" or behavior following rumors. Trading noise behavior caused by lack of investor confidence to their analysis capabilities. This led to decision-making that following rumors/news. Stock purchase decision making that following rumors without careful analysis will produce a high level risk, more than actual risk preferences that can be tolerated. Other investor's behavior was Overtrading. Investors were trading stocks with high frequency. They make many share buying and selling. This contrasts with the investment theory that investment was long term equity participation ${ }^{[1]}$ (Jones, 1998).

Preliminary interview with one investors in Surabaya showed that most individual stock market investors were short-term investors or traders who were buying and selling of stocks on daily, or weekly. According to BR, uncertainty and decision-making errors risk resulting harm, making the psychological factors/emotions play an important role when deciding to buy or sell stocks. Mood investors affected by surrounding environment or preceding events, and their body condition. Ady ${ }^{[2]}(2004)$ found that in doing investment, investors more attention to today return variants than holding stock to get dividend in next year. Most investors do not buy stocks for long term, but they tend to get short-term capital gains.

For a fundamentalist investor, like Warren Buffett ${ }^{[3]}$ (Hagstrom, 2010), short-term investments that tend speculative was wrong. Investors will reduce the benefits due to the transaction costs. The psychological burden was faced by investors because of anxiety and fear in the stock price volatility event.

This big difference view was interesting phenompenom to be researched. This study wants to explore a better understanding of investor's behavior from their own point of view, and understand the meaning of the symptoms that appear in investor behavior. The purpose of this study was to explore the meaning of short-term investments for investors and constructing implementation meaning to decision-making behavior in buying and selling shares for short-term investor in Surabaya, 


\section{Theoretical Review}

Psychological begin to play an important role in decision-making investment that full of risk and uncertainty. Therefore, the investment decision was not to optimize the trade-off between risk and return, such as in conventional finance theory ${ }^{[4]}$ (Markowitz portfolio theory, 1952), the Capital Asset Pricing Model/CAPM ${ }^{[5]}$ (Sharpe, 1964) and efficient markets that began to shift. Human behavior does not have perfect rationality, perfect self-interest, and perfect information (homo economicus/Rational Economic Man (REM)). Rationality was not the only determinant of human behavior. Many psychologists believe that property was subject of human emotions. Human behavior was resulted from more subjective impulse, such as fear, love, hate, pleasure, and pain, rather than logic impulse.

Many studies showed that people do not have perfect personal interest. Therefore, it create developing awareness to others through infak (islamic alms), or giving alms. Some people have perfect or almost perfect information to a particular object, but everyone impossible has perfect knowledge for each subject. A more reasonable assumption was Behaviorally Bias Man (BBM) concept. BBM assumes that individuals choice were but the subjects experienced limitations on knowledge and cognitive capacity, which raises bounded Rationality ${ }^{[6]}$ (Pompian, 2006). Many analysis result showed that in making decisions, investor feelings/psychological determine the decision-making accuracy (Loewenstein, ${ }^{[7]} 2000$; Loewenstein et al, ${ }^{[8]} 2001$; Lucey, ${ }^{[9]} 2005$; Dowling and Lucey, ${ }^{[10]} 2008$ ).

The traditional perspective development had taken potential impact of anticipated emotion (expected emotion) and immediate emotion into decision-making. Anticipated emotion was an emotion that expected to be experienced by decision-makers, while the immediate emotion was an emotion experienced directly at certain decisions. The studies that discussing the expected emotion in investment decision were to show the impact of psychological bias on stock return, as reflected in overconfidence (De Bondt, ${ }^{[11]} 1998$; Campbell, Goodie, \& Foster, ${ }^{[12]} 2004$ ), cognitive dissonance, representativeness bias (Lucey, ${ }^{[9]} 2005$; Shefrin, ${ }^{[13]} 2001,{ }^{[14]} 2005$ ) and loss aversion (Loewenstein et al., ${ }^{[8]} 2001$; Kamstra et al., ${ }^{[15]} 2000$; Hirshleifer and Shumway, ${ }^{[16]} 2003$; Isen, ${ }^{[17]} 2000$; Thaler, ${ }^{[18]} 2000$, Barber and Odean, $\left.{ }^{[19]} 2001\right)$.

Stock market study also considering the impact of feelings to investor decision-making as immediate emotion. It was called a mood misattribution. This study examines the impact of environmental factors, such as weather (Hirshleifer and Shumway, ${ }^{[16]} 2003$; Cao and Wei, ${ }^{[20]} 2005$; Yuksel and Yuksel, ${ }^{[21]} 2009 ; \mathrm{Hu},{ }^{[22]} 2009$ ), body biorhythms (body natural biological cycles) (Kamstra et al., ${ }^{[23]} 2003$; Dowling and Lucey, ${ }^{[10]}{ }^{2008}$ ) and social factors (Shiller, ${ }^{[24]} 1984,{ }^{[25]} 2000$; Hong et al ${ }^{[26]}(2001)$ ) on share price. Mood fluctuations induced by variations in weather and biorhythms of the body can affect stock investment decision.

Durand et al. ${ }^{[27]}(2008)$ examined the psychological variables related to investment decisions and portfolio performance, namely personality and psychological gender. Pompian and Longo ${ }^{[28]}(2004)$ found that over confidence and optimism bias were distinguished by personality type. Lo et al. ${ }^{[29]}(2005)$ found that trade performance was negatively correlated with four of five personality dimensions, with extroversion showed a positive correlation, although there was no statistically significant correlation.

Individual investment behavior was determined by perceptions, attitudes and intentions for investment. Perception and attitude determines one's behavior toward investment time horizon. These values were believed to play an important role in all investor perspective on investment. On the other hand, knowledge of investors about investment theory determines their cognitive analysis level in determining investment instruments and stock selection. Behavioral finance theory determines the emotional stability level and bias in any investment behavior when adapting to a various events in capital markets. Investment decision theory of Loewenstein ${ }^{[8]}(2001)$ become basis theory in deciding share buying and selling. Investment decision, in this case was stock buying and selling, will be influenced by many factors that integrated holistically.

\section{Research Methods}

This study used a qualitative interpretive paradigm with Schutz's phenomenological method and study the moral aspect of deontology, to interpret investors behavior and to construct investor behavior models. Informants was determined using purposive and snowball technique. Methods for collecting data were in-depth interviews, participant observation, and documentation. The data was analyzed using phenomenology analysis of Mustakas ${ }^{[30]}(1994)$. Criteria used to determine data validity, to determine validity and reliability of qualitative data, was the transferability, credibility/trustworthiness (It tested using triangulation, member checking, and external audit), authenticity/confirmability (was decided by bracketing and epoche) and dependability (Daymon and Holloway, ${ }^{[31]} 2007$; Shenton, ${ }^{[32]} 2004$ ). 


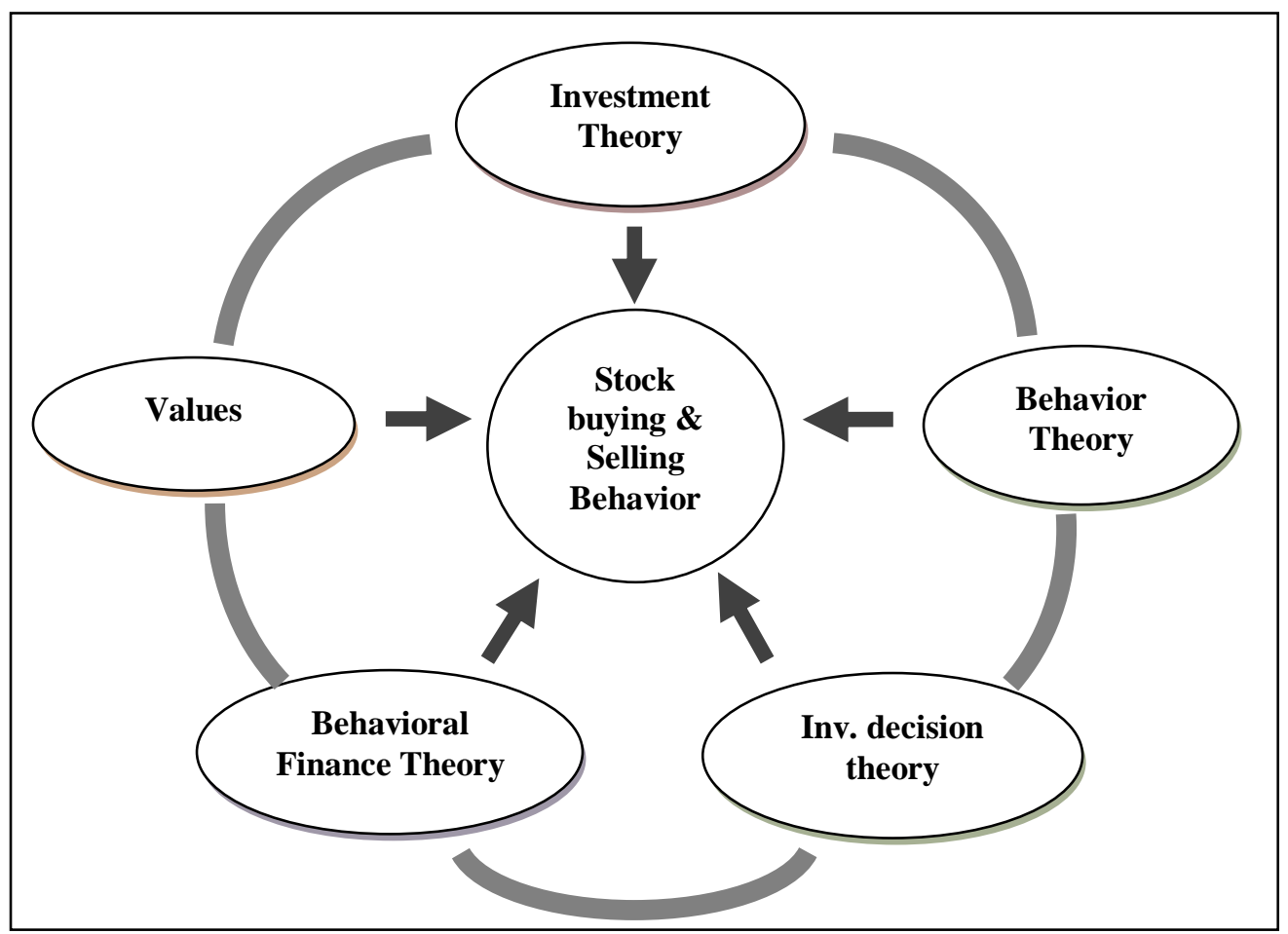

Figure 1.Theoritical Framework

\section{Result And Discussion}

The informants for this study were 5 investor. They age were between 18-52 years old. The five informants were investors who invested in stock at least three years from now, so they could reflect their experience in investment.

The results of this study found the investors' perceptions on investment meaning and reason they make stocks investment could determine the motive and categories and identity of each investing investor. It create typical behavior. There were three kinds of investors motives. "Because" motive explain that reason of share investment as -past-oriented, "Therefore" motive was present-oriented, and 'in order to' motive was futureoriented. Schematically, a description of the reasons, motives and investor characteristics category can be described as follows:

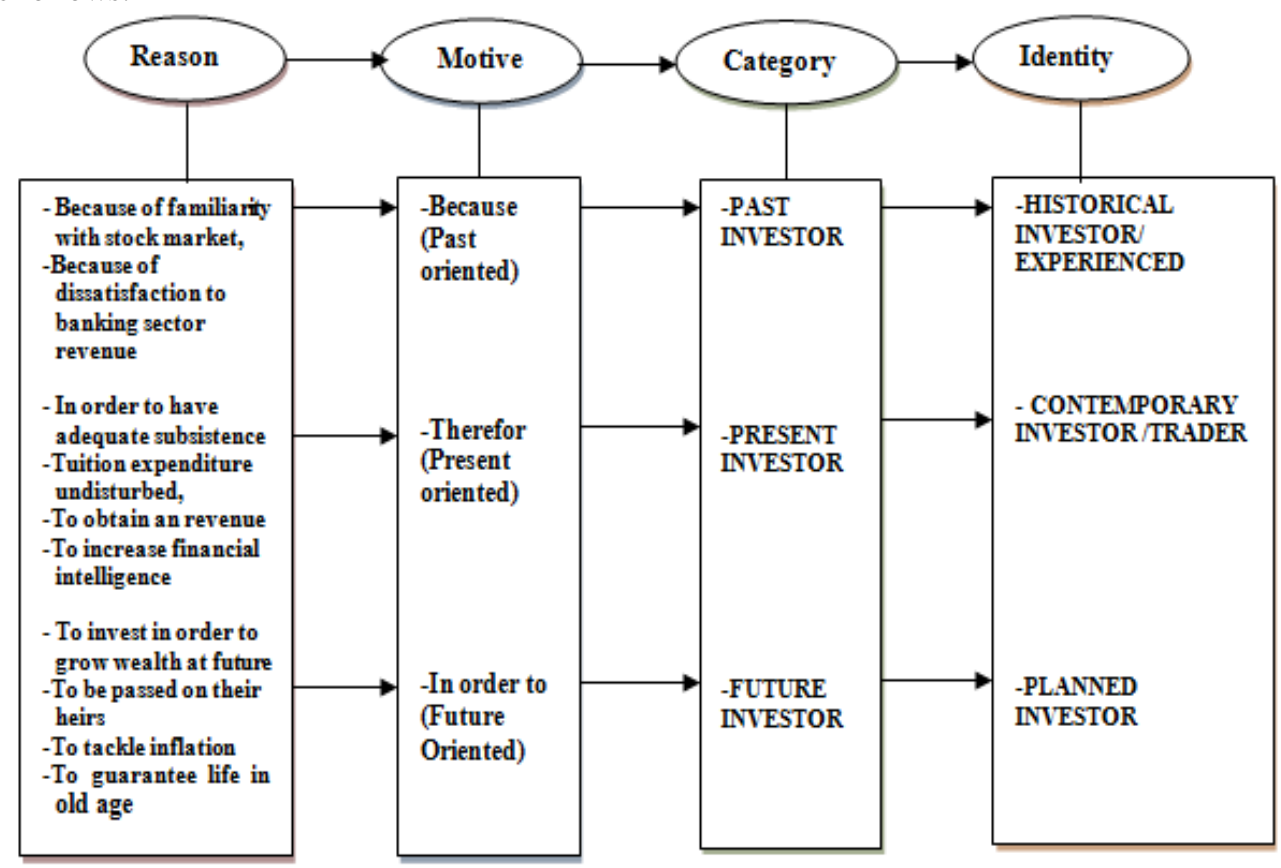

Figure 2. Model Process Informan Became to be Investor 


\subsection{Investor Identity \\ 4.1.1. Historical Investors}

Historical investors represented by LT. LT had a motive to invest because academically they have sufficient knowledge in the capital markets field. So he wants to apply his knowledge to deal directly as an investor. LT buy and sell shares within 3 to 6 months period. Basis for decision making was to find undervalued stocks and resale them when the stock had above the standard price predictions, although only held in a few months. The decision to buy or to sell shares was done with a fairly complex analysis, namely: (1) fundamental analysis by looking at the macro conditions, (2) industry analysis, (3) financial statements analysis, to see company EPS growth compared to PER (4) to distinguish between good-company good-stock and bad-company bad-stock, (5) technical analysis for confirmation

\subsubsection{Contemporary Investor/trader}

Contemporary investor or trader make share investment-oriented with today orientation, as to make a profit, increase family incomes, and so on. There were 3 kinds of traders were found, namely:

- Day traders, represented by ER, conduct daily transactions. Decision to buy and to sell shares was done by following stages: (1) pay attention to rumors, (2) technical analysis/chart, (3) who was enter when they get out, (4) the target gains and losses

- Swing traders, represented by IAN, conduct weekly transactions. Decision to buy and to sell shares was done by following stages: (1) Selecting a bluechip shares with good news, (2) analyzing the fundamentals and background of company, (3) making technical analysis to determine the incoming momentum, (4) If a lot of investors, including foreign investors, buy the share, it would strengthening the incoming momentum.

- Position traders, represented by WS. He make monthly transactions (1-3 months). Decision to buy and to sell shares was done by following stages: (1) macro analysis, what thing was required by the country at this time, (2) selection of industry sectors, (3) company financial statements analysis, (4) What would be done by company/corporate action ( 5 ) technical for confirmation

\subsubsection{Future Investors/ Planned Investor}

Future investors/planned investor were buying and holding investors. This investors represented by SI. SI would buy shares and never make a sale unless the funds will be used for other needs. It was Intended for longterm investment and becoming a passive investor. The analysis in share buying and selling decision were : (1) simple macroeconomic analysis, (2) selecting a growing company, (3) selecting shares that actively traded, (4) selecting a clear company, (5) select a government-owned company

Investors behavior in shares buying and selling decisions were not free from psychological influence. This create behavior bias on stock selection. Psychological bias made by five informants were:

1. Overconfidence, informants too confident because they have better information and knowledge than others. This causes Overtrading behavior, underestimate the risk, and holds a bad diversified portfolio. It occurs in almost all informants.

2. Representative bias, informants make simple classification according to the information held. It often occurs to the SI and ER.

3. Loss aversion, informants have greater incentive to avoid losses, by holding loss stocks longer. It happens to WS, SI, IAN and ER informant.

4. Cognitive dissonance, informants feel mental/psychological discomfort when there was a mismatch between the new information with their understanding and believes. As a result, investors retain an underperforming stock, make lower average, herding behavior.

5. Availability bias was a cognitive bias where people tend to make estimates based on proximity/familiarity with their lives. This was often done by SI and ER in determining which stocks selected, based on the large company, state-owned and so on.

6. Self attribution bias, informants tended to describe the success experienced by factors from within himself and failure comes from external factors. This causes overconfidence, Overtrading, holding underdiversified portfolio. It often occurs in the SI and ER.

\subsection{Investor Behavior Exploration Based on Age, Gender, Personality/character, Education and Experience}

Investor behavior exploration based on age, gender, personality/character, education and experience can be seen in the following table: 
Tabel 1.

Investor Behavior Exploration Based age, Gender, Personality/character, Education dan Experience

\begin{tabular}{|c|c|c|c|c|c|}
\hline Informan & LT & WS & SI & IAN & ER \\
\hline \hline Age & 47 & 36 & 52 & 18 & 40 \\
\hline Gender & $\mathrm{M}$ & $\mathrm{M}$ & $\mathrm{M}$ & $\mathrm{M}$ & $\mathrm{F}$ \\
\hline $\begin{array}{c}\text { Personality/ } \\
\text { Character }\end{array}$ & Individualist & Adventurer & Guardian & Individualist & Celebrity \\
\hline $\begin{array}{c}\text { Experience } \\
\text { (year) }\end{array}$ & 16 & 14 & 12 & 4 & 16 \\
\hline $\begin{array}{c}\text { Trader/ } \\
\text { Investor } \\
\text { Type }\end{array}$ & $\begin{array}{c}\text { Historical } \\
\text { Investor }\end{array}$ & $\begin{array}{c}\text { Position } \\
\text { Trader }\end{array}$ & $\begin{array}{c}\text { Investor } \\
\text { Berencana }\end{array}$ & Swing Trader & Day trader \\
\hline $\begin{array}{c}\text { Education } \\
\text { Average } \\
\text { Return /year } \\
\text { (\%) }\end{array}$ & $\begin{array}{c}\text { Postgraduate } \\
\text { (S3) }\end{array}$ & $\begin{array}{c}\text { Postgraduate } \\
\text { (S2) }\end{array}$ & Bachelor (S1) & High School & High School \\
\hline
\end{tabular}

Investor behavior exploration by age shows that young people do not show higher levels of aggression. IAN was 18 years old. He did not choose to become a day trader (daily deal) because he does not have time monitor the market continously. Based on personality, IAN choose become swing trader that more agile, due he like to be an active investor rather than a passive investor who tend to buy and hold share.

Investor behavior exploration could be based on personality. In this case, researchers saw investors under the extrovert/introvert personality and psychographics of BB \& K (The Bailard, Biehl and Kaiser) Pompian ${ }^{[6]}(2006)$ can be seen in Figure 2. LT and IAN was Individualist typical Investor. Investors likely have their own way of doing investment analysis. Selection to buy shares was done by careful analysis and thorough. Detailed planning was done, including decision to sell shares. The decisions will be made more rational and minimizing the psychological/emotional.

WS was Adventurer investor typical. He prefers risk. Investment decisions were often based news or momentum that being "hot". He has his own ideas about investing and he have high confidence.

SI was Guardian investor typical. SI very careful in selecting stocks, but have low confidence. In any investment decision, SI always ask to broker, because lack of confidence. SI do not like volatility. Therefore, SI invest in the long term share. SI makes analysis stock selection, albeit modest.

ER was the Celebrity investors typical. ER does not have its own ideas and ways to invest. Herd investment decision-making was often based on friends influence, broker or neighborhood. ER tend to be less careful in making decisions and careful planning. ER Frequently buy share and can not sell, so he hold the stock for years.

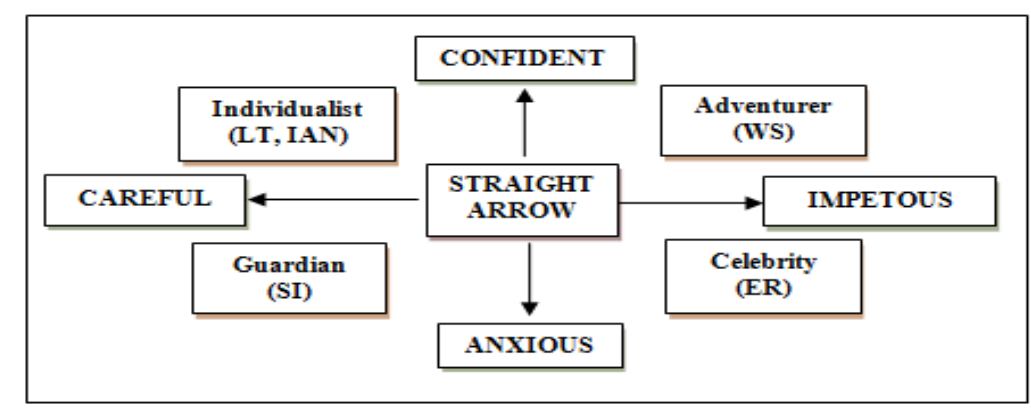

Figure 3. BB\&K Model Applied

Researchers looked at the introvert or extrovert of an informant based on the perception of himself and those around him. Extroverts was typically someone with outside orientation, sociable, energetic, confident, communicative and enthusiastic. Introvert was someone who tend to be shy, timid, rarely speaking if not feel necessary, quiet, not outgoing, in home people ${ }^{[33]}$ (Ajzen, 2005).

In this observational study, WS, ER, and SI tend more extroverted, more open, sociable. Investment decision often influenced by other people or the environment, such as a broker, investor friends, rumors, and so 
on. ER often trade stocks because of rumors evolve, as it follows the foreign investors (herding) or noise in the market.

Investor behavior exploration by gender found that women prefer risk by choosing to transact with a very short period of time. This was represented by the informant ER. Compared to the four men, preferring ER trading period was longer.

Investor behavior exploration by education shows that LT education, in postgraduate scholar program with capital market major, help him in determining his investment behavior. LT was more rational. He uses careful analysis. Therefore, LT obtain higher average return per year compared to most other informants.

Investor behavior exploration based on experience shows that LT experienced longer dabbling in stock market. This produces a better learning effect in overcoming psychological problems and adapt to all the changes and dynamics in the capital markets.

Based on above discussion, it can be arranged minor and major proposition as follows:

PM1 : Age does not indicate the level of aggressiveness behavior if it was not supported by more time availability to monitor the market.

PM2 : Age does not indicate a higher risk preference if it was not supported by supporting personality type of investor

PM3 : Women prefer to risk by choosing to trade in a very short period and with riskier share than men

PM4 : Compared to other short-term investors types, such as swing trader, position trader, and historical investors, day traders have the greatest psychological burden in decision-making to buy or to sell shares

P1 : Compared with fundamental analysis and technical analysis, investor/trader with better emotions management based on age, gender, education and personality become central point in determining the investor/trader success.

P2 : Short-term investors can manage emotions rightly by acquiring short-term investment gains that outweigh the long-term investment.

P3 : Experience was the best teacher for the a trader career journey. Traders who managed to make the learning experience will be better than the traders who understand the science of stock market but lack experience, because the decisions based on a combination of rational and intuitive.

\subsection{Behavior Model Construction of stock buying and selling by Short Term Investors}

Construction of behavioral models of stock buying and selling $\mathrm{s}$ on short-term investors based on the results obtained by the above analysis. Behavior of short term investors buying and selling shares fraught with risks and uncertainties. It was influenced by the following factors: (1) perceptions, (2) attitudes, (3) intention, (4) Learning

Integrally, the fourth variable affects the behavior of share buying and selling. Investors will behave according to the perceptions and attitudes he believes. It creates motive and identity for then. Generally, an experienced investor, a trader or an investor did not plan to analyze stock together with decision-making time to buy shares, except for day traders. At this stage, various influences come from the values they believe in shaping the attitudes and perceptions of their behavior.

Investors/traders analyses the share during the night or morning before purchase shares on next day. At this time, they perform various rational analyzes, both fundamental and technical, to determine the shares to be purchased. In the process of analyzing and selecting share, psychological factors may influence the decisionmaking, based on how long they were experienced in capital markets. The longer experience in the capital markets and the sharper the learning process was done then the smaller psychological disturbance in analysis. Psychological factors that influence this phase was expected emotion. Investors can imagine the joy feeling when buying stocks and then the price increases. But instead, investors were also feeling disappointed if the shares purchased has decreased the price. At this psychological stage overconfidence often appears. Investor or trader was too much confident that they have more information than others, so they make analysis in accordance with their beliefs.

Another thing that may affect the representativeness bias stage was the stock selection was not based on good stock but by good company, or well known companies, large companies, companies' stock price actually no longer undervalued and cognitive dissonance. Generally, they established a trading plan based on risk preferences. Risk preference was influenced by demographic variables, such as age, gender, education, wealth and character/personality. Immediate emotion was experienced investor/trader at decision making time. There were two kinds of immediate emotion. Integral emotion comes from fear and greed associated with their investment. Incidental emotion was an emotion that was affected by factors that were not associated with any investment decision. Incidental emotion was influenced by factors such as biological, mood, sadness, external conditions, and so on. Overall, the emotions were influenced by age, gender, personality and experience. Everything will become a learning process. This process will be repeated. Experience will modify pre-existing perceptions. Traders who managed to make the experience as a learning process will be able to become a good 
trader. Consistently, they make benefit from the investment. Holistically, behavioral models figure of short-term investors decision making could be shown as follows:

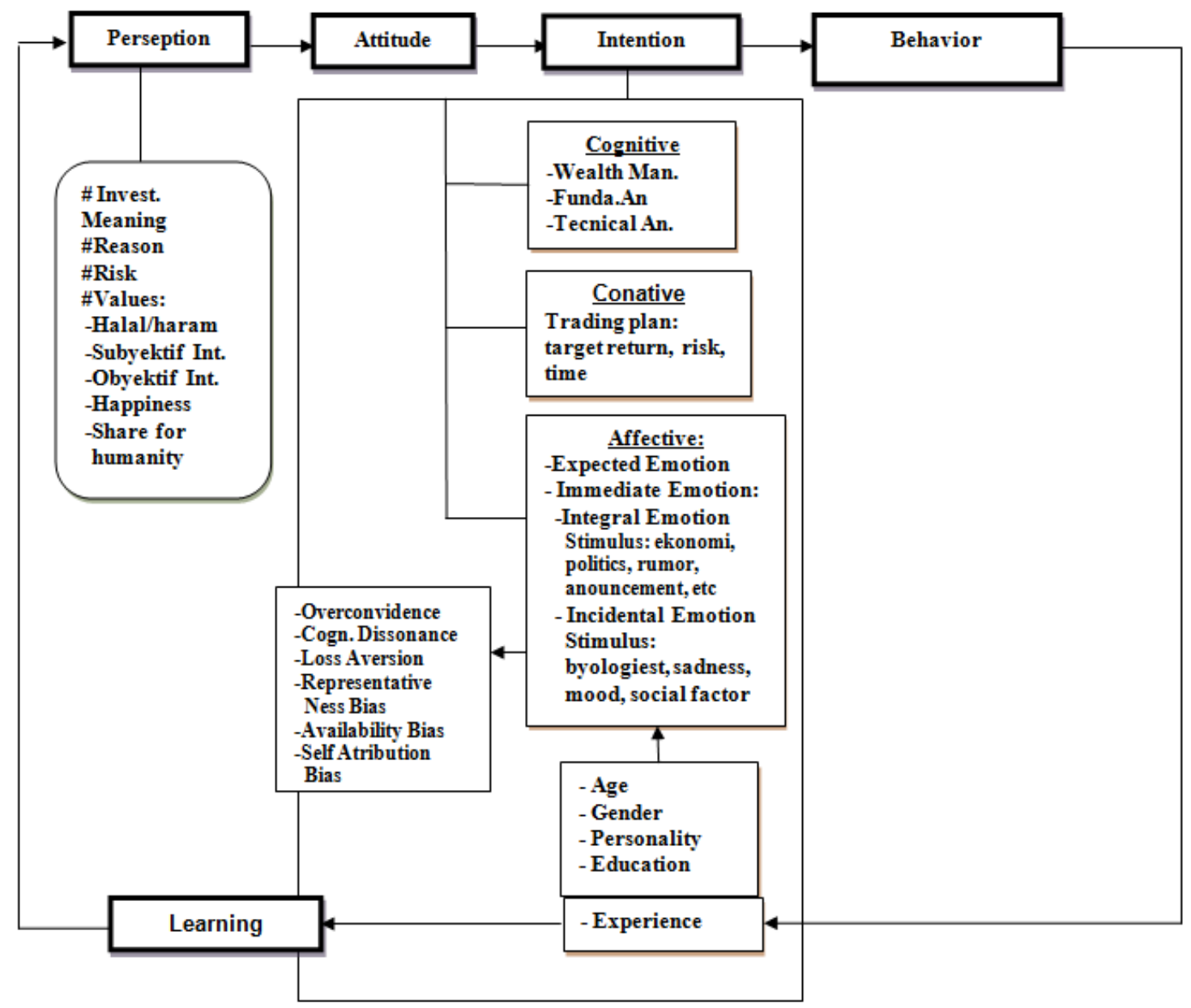

Figure 4.

\section{Model Construction of Stock Buying and Selling Behavior's} Short Term Investor

\section{Conclusion}

The results of this study indicate that investors often show irrational behavior. They tend to be influenced by psychological factors, such as overconfidence, loss aversion, cognitive dissonance, representativeness bias, self-attribution bias and so on. This makes them become overtrading, herding and noise trading. Phenomenology makes one know the essence of a behavior, not only look at the symptoms appear. Therefore, the improvement process will more sensible and effective.

\section{References}

[1] C. P. Jones, Investment, Analysis and Management, Sixth Edition (John Wiley \& Son, Inc. USA). 1998.

[2] S. U. Ady, Analysis Variables influenced Toward Stock Price Spread in Manufacture Industry in Indonesia Stock Exchange, Journal, Economic and Business Magazine, Dr. Soetomo University, 4 (2) 2004: 36-57.

[3] R. G. Hagstrom, the Warren Buffet Portfolio: Mastering the power of the focus Investment Strategy (Zaimur, Yelfi Andri (Translator), Daras Books, 2010).

[4] H. Markowitz, Portofolio selection, The Journal of Finance 7(1) 1952, 77-91.

[5] W. F.Sharpe, Capital asset prices: A theory of market equilibrium under conditions of risk. Journal of Finance 19 (3), 1964, 425442

[6] M. M. Pompian, Behavioral finance and wealth management, how to build optimal portofolios that account for investor biases. $1^{\text {st }}$ (John Wiley \& Son, Inc. USA, 2006).

[7] G. Loewenstein, Emotion in economic theory and economic behavior. American Economic Review 65, 2000, 426-432

[8] G. Loewenstein, E. U. Weber, C. K. Hsee, and N. Welch, Risk as feeling, Psychological Bulletin 127, 2001, $267-286$.

[9] B. M. Lucey, The role of feeling in infestor decision-making. Jounal Of Economic Surveys, 19, (2), $2005,212-237$.

[10] M. Dowling, and B. M. Lucey, Robust global mood influence in equity pricing, Journal of Multinational Financial Management 18, 2008, 145-164

[11] W. F. M. De Bondt, A portrait of the Individual investor. European Economic Review 42, 1998, 831-844. 
[12] W. K. Campbell, A. S. Goodie, \& J.D. Foster, Narcissim, convidence, and risk attitude. Journal of Behavioral Decision Making, 17, 2004, 297-311.

[13] H. Shefrin, Do investors expect higher returns from safer stocks than from riskier stocks? Journal of Psychology and Financial Markets 2, 2001, 176-181.

[14] H. Shefrin, A Behavioral Approach to Asset Pricing, Elsevier Academic Press, 2005.

[15] M. J. Kamstra, L. A. Kramer, and M. D. Levi, Losing sleep at the market: the daylight-savings anomaly. American Economic Review 90 (4) 2000, 1005-1011.

[16] D. Hirshleifer, David, dan Shumway, Tyler good day sunshine: stock return and the weather. Journal of Finance, 58, (3), 2003, 1009-1032.

[17] A. M. Isen, Positive affect and decision making. In J. M. Haviland (ed.), Handbook of Emotions (London: Guilford Press, 2000) 261-277.

[18] R. H. Thaler, From homo economicus to homo sapiens. Journal of Economic Perspectives 14(1), 2000, 133-141.

[19] B. M. Barber, T. Odean, Boys will be boys: gender, overconvidence, and common stock investment. Quarterly Journal of Economics, 116, 2001, 261-292.

[20] M. Cao, dan J. Wei, Stock market returns: a note on temperature anomaly, Journal of Banking \& Finance 29, $2005,1559-1573$.

[21] A. Yuksel, and A. Yuksel, Stock return seasonality and the temperature effect. International Research Journal of Finance and Economics, Issue 34, 2009, 107-116.

[22] J. Hu, Does weather matter? Departemental Working Paper, Department of Economic, Southern Methodist University, No.080, 92009, 1-24.

[23] M. J. Kamstra, L. A.Kramer, and M. D. Levi, Winter blues: a sad stock market cycle. American Economic Review 93 (1), 2003 : 324-343.

[24] R. J. Shiller,. Stock prices and social dynamics. Brookings Papers on Economic Activity 2, 1984, 457-510.

[25] R. J. Shiller, Conversation, information, and herd behavior. American Economic Review 85, 2000, 181-185.

[26] H. Hong, J. D Kubik,. and J. C. Stein,. Social interaction and stock-market participation. Working Paper, SSRN.com

[27] Robert B. Durand, et al. An intimate portrait of the individual investor. Journal of Behavioral Finance 9 (44) 2008: 193-208.

[28] M. M. Pompian, and M. M. Longo, A New Paradigm for Practical Application of Behavioural Finance: Creating Investment Programs Based on Personality Type and Gender to Produce Better Investment Outcomes. The Journal of Wealth Management(Fall) 2004, 1 - 7 .

[29] A. W. Lo, D. V. Repinz and B. N. Steenbargery, Fear and greed in financial markets: a clinical study of day traders. Working Paper, MIT Sloan School of Management, 2005.

[30] C. Moustakas, Phenomenological Research Methods (Sage Publication Inc. USA. 1994).

[31] C. Daymon, and I. Holloway, Qualitative research methods on Public Relation and Marketing Communiccation, Translate by Cahya Wiratama, Bentang, Yogyakarta. 2007.

[32] A.K. Shenton, Strategies for ensuring trustworthiness in qualitative research projects. Education for Information. 22, $2004: 63-75$.

[33] I. Ajzen, Attitude, Personality and Behavior, $2^{\text {nd }}$ ed (McGraw-Hill, NY, 2005.)

\section{Appendix}

Inter-Site Analysis, Decision-making Behavior Phenomenon of Stockgm Selling and buying

\begin{tabular}{|c|c|c|c|c|c|c|}
\hline \multirow{2}{*}{$\begin{array}{l}\mathbf{N} \\
\mathbf{O}\end{array}$} & \multirow[t]{2}{*}{ THEME } & \multicolumn{5}{|c|}{ INFORMAN } \\
\hline & & LT & WS & SI & IAN & ER \\
\hline 1. & $\begin{array}{l}\text { 1. Investment reasons: } \\
\text { a. The dissatisfaction to banking } \\
\text { sector profits } \\
\text { b. Need extra income } \\
\text { c. Take Capital Markets major at } \\
\text { graduate and postgraduate } \\
\text { education } \\
\text { d. Need money quickly for college } \\
\text { tuition } \\
\text { e. Increase the wealth in future } \\
\text { f. To inherited to their descent } \\
\text { g. Investment in stocks was very } \\
\text { favorable } \\
\text { h. Protect your funds from inflation } \\
\text { i. Improving financial intelligence } \\
\text { j. Assumes the shares world was the } \\
\text { future world } \\
\text { k. To guarantee the life in old age. }\end{array}$ & $\begin{array}{l}\sqrt{ } \\
\sqrt{ } \\
\sqrt{ } \\
\sqrt{ }\end{array}$ & $\begin{array}{l}\sqrt{ } \\
\sqrt{ } \\
\sqrt{ } \\
\sqrt{ } \\
\sqrt{ }\end{array}$ & $\begin{array}{l}\sqrt{ } \\
\sqrt{ } \\
\sqrt{ } \\
\sqrt{ }\end{array}$ & $\begin{array}{l}\sqrt{ } \\
\sqrt{ } \\
\sqrt{ }\end{array}$ & $\begin{array}{l}\sqrt{ } \\
\sqrt{ }\end{array}$ \\
\hline
\end{tabular}




\begin{tabular}{|c|c|c|c|c|c|c|}
\hline \multirow{2}{*}{$\begin{array}{l}\mathbf{N} \\
\mathbf{O}\end{array}$} & \multirow[t]{2}{*}{ THEME } & \multicolumn{5}{|c|}{ INFORMAN } \\
\hline & & LT & WS & SI & IAN & $\overline{\text { ER }}$ \\
\hline 2. & $\begin{array}{l}\text { The investment motive: } \\
\text { a. 'Because' motive (past } \\
\text { orientation): } \\
\text { - Because they felt very } \\
\text { familiar with stock market, } \\
\text { due when graduate and } \\
\text { postgraduate always take } \\
\text { capital market major } \\
\text { - Because of dissatisfaction } \\
\text { to banking sector revenue } \\
\text { - Because following family } \\
\text { b. 'Therefore' motive (present } \\
\text { orientation): } \\
\text { - In order to have adequate } \\
\text { subsistence } \\
\text { - Tuition } \\
\text { undisturbed, expenditure } \\
\text { - To obtain an revenue } \\
\text { - To increase financial } \\
\text { intelligence } \\
\text { c. 'In order to' motive (Future } \\
\text { Orientation): } \\
\text { - To invest in order to grow } \\
\text { - Toalth at future } \\
\text { - To be passed on their heirs } \\
\text { - To guarantee life in old age }\end{array}$ & $\begin{array}{l}\sqrt{ } \\
\sqrt{ }\end{array}$ & $\begin{array}{l}\sqrt{ } \\
\sqrt{ } \\
\sqrt{ }\end{array}$ & $\begin{array}{l}\sqrt{ } \\
\sqrt{ } \\
\sqrt{ } \\
\sqrt{ }\end{array}$ & $\begin{array}{l}\sqrt{ } \\
\sqrt{ }\end{array}$ & $\begin{array}{l}\sqrt{ } \\
\sqrt{ } \\
\sqrt{ }\end{array}$ \\
\hline 3. & $\begin{array}{l}\text { Category: } \\
\text { a. Experienced Investor } \\
\text { b. Trader } \\
\text { c. Planned Investor }\end{array}$ & $\sqrt{ }$ & $\sqrt{ }$ & $\sqrt{ }$ & $\sqrt{ }$ & $\sqrt{ }$ \\
\hline 4. & $\begin{array}{l}\text { Identity: } \\
\text { a. Medium term investment (3-6 } \\
\text { months), } \\
\text { b. Short term investment (less than } 3 \\
\text { months), } \\
\text { c. Long-term investment }\end{array}$ & $\sqrt{ }$ & $\sqrt{ }$ & $\sqrt{ }$ & $\sqrt{ }$ & $\sqrt{ }$ \\
\hline 5. & $\begin{array}{l}\text { Investment definition: } \\
\text { a. Delay consumption today for } \\
\text { future benefits } \\
\text { b. Investment does not mean to sell } \\
\text { over the next year, when in a } \\
\text { month already profit/hit the } \\
\text { target, sold, } \\
\text { c. Since the share purchase based on } \\
\text { financial statements, a share will } \\
\text { undervalued, but did not know } \\
\text { when the price rise } \\
\text { d. How to develop faster funding, to } \\
\text { avoid inflation, } \\
\text { e. How to manage your money for a } \\
\text { better life in the future }\end{array}$ & $\begin{array}{l}\sqrt{ } \\
\sqrt{ } \\
\sqrt{ }\end{array}$ & $\begin{array}{l}\sqrt{ } \\
\sqrt{ } \\
\sqrt{ }\end{array}$ & $\sqrt{ }$ & $\begin{array}{l}\sqrt{ } \\
\sqrt{ }\end{array}$ & $\begin{array}{l}\sqrt{ } \\
\sqrt{ } \\
\sqrt{ }\end{array}$ \\
\hline
\end{tabular}




\begin{tabular}{|c|c|c|c|c|c|c|}
\hline \multirow{2}{*}{$\begin{array}{l}\mathbf{N} \\
\mathbf{O}\end{array}$} & \multirow[t]{2}{*}{ THEME } & \multicolumn{5}{|c|}{ INFORMAN } \\
\hline & & LT & WS & SI & IAN & ER \\
\hline 6. & $\begin{array}{l}\text { Shares Investment Preparation: } \\
\text { a. Target return and target risk/dead } \\
\text { line } \\
\text { b. If making profit don't be greedy. } \\
\text { Profit 5-10\% a month was } \\
\text { enough. If get loss, a share loss } \\
20 \% \text {, the share was sold } \\
\text { c. If making profit, don't complacent } \\
\text { d. Do not use debt funds } \\
\text { e. Not to use the money for everyday } \\
\text { needs } \\
\text { f. Use money that not used in short } \\
\text { term } \\
\text { g. Do not put all your money } \\
\text { h. Have confidence and references } \\
\text { i. Do not get into stuff that being } \\
\text { sharpened } \\
\text { j. Do not enter if you were not } \\
\text { strong mentally } \\
\text { k. Learn the capital markets } \\
\text { knowledge to minimize the risk }\end{array}$ & $\begin{array}{l}\sqrt{ } \\
\sqrt{ } \\
\sqrt{ } \\
\sqrt{ } \\
\sqrt{ } \\
\sqrt{ } \\
\sqrt{ } \\
\sqrt{ } \\
\sqrt{ }\end{array}$ & $\begin{array}{l}\sqrt{ } \\
\sqrt{ } \\
\sqrt{ } \\
\sqrt{ } \\
\sqrt{ } \\
\sqrt{ } \\
\sqrt{ } \\
\sqrt{ }\end{array}$ & $\begin{array}{l}\sqrt{ } \\
\sqrt{ } \\
\sqrt{ } \\
\sqrt{ } \\
\sqrt{ } \\
\sqrt{ } \\
\sqrt{ } \\
\sqrt{ }\end{array}$ & $\begin{array}{l}\sqrt{ } \\
\sqrt{ } \\
\sqrt{ } \\
\sqrt{ } \\
\sqrt{ } \\
\sqrt{ } \\
\sqrt{ } \\
\sqrt{ } \\
\sqrt{ }\end{array}$ & $\begin{array}{l}\sqrt{ } \\
\sqrt{ } \\
\sqrt{ } \\
\sqrt{ }\end{array}$ \\
\hline 7 & $\begin{array}{l}\text { Analysis of the Decision-making } \\
\text { stock purchase: } \\
\text { a. Macro economy analysis } \\
\text { b. Industry Analysis } \\
\text { c. Company analysis } \\
\text { d. P/E Ratio Analysis } \\
\text { e. Checklist strength-weakness } \\
\text { analysis } \\
\text { f. Good company-good stock bad- } \\
\text { company bad-stock analysis } \\
\text { g. Technical Analysis } \\
\text { h. Stock selection based on rumor } \\
\text { i. Who was playing there, who's in } \\
\text { there and when to exit } \\
\text { j. Active stocks traded } \\
\text { k. The company was clearly visible } \\
\text { 1. State-owned company } \\
\text { m. Fried stock } \\
\text { n. Looking for LQ45 Blue chip } \\
\text { stock } \\
\text { o. Growing stock. }\end{array}$ & $\begin{array}{l}\sqrt{ } \\
\sqrt{ } \\
\sqrt{ } \\
\sqrt{ } \\
\sqrt{ } \\
\sqrt{ } \\
\sqrt{ }\end{array}$ & $\begin{array}{l}\sqrt{ } \\
\sqrt{ } \\
\sqrt{ } \\
\sqrt{ }\end{array}$ & $\begin{array}{l}\sqrt{ } \\
\sqrt{ } \\
\sqrt{ }\end{array}$ & $\begin{array}{l}\sqrt{ } \\
\sqrt{ } \\
\sqrt{ } \\
\sqrt{ }\end{array}$ & $\begin{array}{l}\sqrt{ } \\
\sqrt{ } \\
\sqrt{ }\end{array}$ \\
\hline 8. & $\begin{array}{l}\text { Share Selling Decision Analysis: } \\
\text { a. Based on a specific target, either } \\
\text { gains or losses } \\
\text { b. The maximum loss/share of } 20 \% \text {, } \\
\text { wait a maximum } 1 \text { month, if } \\
\text { nothing changes, cutloss } \\
\text { c. Emotional effect, especially loss } \\
\text { aversion, because money was } \\
\text { already invested } \\
\text { d. Under certain references } \\
\text { e. Reading historical/technical } \\
\text { f. Based on rumors } \\
\text { g. Overconfidence, as in the case }\end{array}$ & $\begin{array}{l}\sqrt{ } \\
\sqrt{ } \\
\sqrt{ } \\
\sqrt{ } \\
\sqrt{ } \\
\sqrt{ } \\
\sqrt{ }\end{array}$ & $\begin{array}{l}\sqrt{ } \\
\sqrt{ } \\
\sqrt{ } \\
\sqrt{ } \\
\sqrt{ } \\
\sqrt{ } \\
\sqrt{ } \\
\sqrt{ } \\
\end{array}$ & $\sqrt{ }$ & $\begin{array}{l}\sqrt{ } \\
\sqrt{ } \\
\sqrt{ } \\
\sqrt{ } \\
\sqrt{ } \\
\sqrt{ }\end{array}$ & $\begin{array}{l}\sqrt{ } \\
\sqrt{ } \\
\sqrt{ } \\
\sqrt{ } \\
\sqrt{ } \\
\sqrt{ } \\
\sqrt{ }\end{array}$ \\
\hline
\end{tabular}




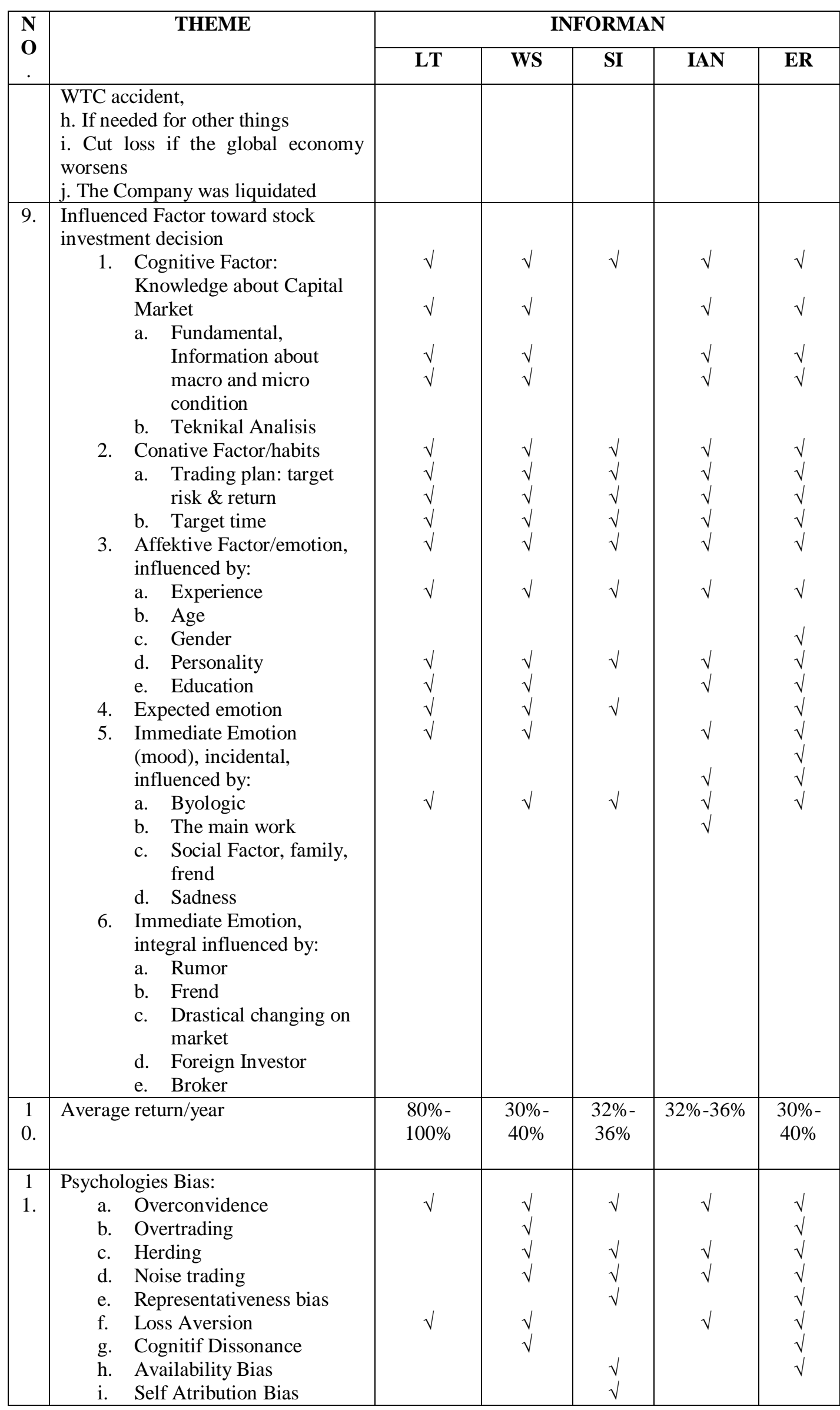




\begin{tabular}{|c|c|c|c|c|c|c|}
\hline \multirow{2}{*}{$\begin{array}{l}\mathbf{N} \\
\mathbf{O}\end{array}$} & \multirow[t]{2}{*}{ THEME } & \multicolumn{5}{|c|}{ INFORMAN } \\
\hline & & LT & WS & SI & IAN & ER \\
\hline $\begin{array}{l}1 \\
2 .\end{array}$ & $\begin{array}{cl}\text { Identitas } & \text { Diri } \\
\text { a. } & \text { Age } \\
\text { b. } & \text { Marital status } \\
\text { c. } & \text { Gender } \\
\text { d. } & \text { Amount of children } \\
\text { e. } & \text { Spiritual Belief } \\
\text { f. } & \text { Personality } \\
\text { g. } & \text { Introvert/ekstrovert } \\
\text { h. } & \text { Etnics }\end{array}$ & $\begin{array}{c}47 \\
\text { Maried } \\
\text { M } \\
2 \\
\text { Islam } \\
\text { Carefully, } \\
\text { analitis, } \\
\text { Introvert } \\
\text { Java }\end{array}$ & $\begin{array}{l}36 \\
\text { Maried } \\
\text { M } \\
2 \\
\text { Islam } \\
\text { adventu } \\
\text { rer, } \\
\text { ekstrov } \\
\text { ert } \\
\text { Java }\end{array}$ & $\begin{array}{l}52 \\
\text { Maried } \\
\text { M } \\
3 \\
\text { Islam } \\
\text { Carefu } \\
\text { lly, } \\
\text { ekstro } \\
\text { vert } \\
\text { Java }\end{array}$ & $\begin{array}{c}18 \\
\text { No } \\
\text { Maried } \\
\mathrm{M} \\
- \\
\text { Islam } \\
\text { Carefully, } \\
\text { analitis,in } \\
\text { trovert } \\
\text { Java }\end{array}$ & $\begin{array}{l}40 \\
\text { Maried } \\
\mathrm{F} \\
1 \\
\text { Islam } \\
\text { impeto } \\
\text { us } \\
\text { Ektrov } \\
\text { ert } \\
\text { Java }\end{array}$ \\
\hline $\begin{array}{l}1 \\
3 .\end{array}$ & Start to trade in the capital market & 1996 & 1998 & 2000 & 2008 & 1996 \\
\hline $\begin{array}{l}1 \\
4 .\end{array}$ & $\begin{aligned} \text { Values: } & \\
\text { a. } & \text { Halal/haram } \\
\text { b. } & \text { Subyektif Interest } \\
\text { c. } & \text { Obyektif Interest } \\
\text { d. } & \text { The meaning of share for } \\
& \text { humanity } \\
\text { e. } & \text { The meaning of Happiness }\end{aligned}$ & $\begin{array}{l}\sqrt{ } \\
\sqrt{ } \\
\sqrt{ } \\
\sqrt{ } \\
\sqrt{ }\end{array}$ & $\begin{array}{l}\sqrt{ } \\
\sqrt{ } \\
\sqrt{ } \\
\sqrt{ } \\
\sqrt{ }\end{array}$ & $\begin{array}{l}\sqrt{ } \\
\sqrt{ } \\
\sqrt{ } \\
\sqrt{ } \\
\sqrt{ }\end{array}$ & $\begin{array}{l}\sqrt{ } \\
\sqrt{ } \\
\sqrt{ } \\
\sqrt{ } \\
\sqrt{ }\end{array}$ & $\begin{array}{l}\sqrt{ } \\
\sqrt{ }\end{array}$ \\
\hline
\end{tabular}

